\title{
Physiological Responses of Earthworm Under Acid Rain Stress
}

\author{
Xuan Chen ${ }^{1}$, Jiaen Zhang ${ }^{1,2,3,4, *}$ and Hui Wei ${ }^{1,2,3,4}$ \\ 1 College of Natural Resources and Environment, South China Agricultural University, Guangzhou 510642, \\ China; xuanchen@stu.scau.edu.cn (X.C.); weihui@scau.edu.cn (H.W.) \\ 2 Guangdong Provincial Key Laboratory of Eco-Circular Agriculture, Guangzhou 510642, China \\ 3 Guangdong Engineering Research Center for Modern Eco-agriculture and Circular Agriculture, \\ Guangzhou 510642, China \\ 4 Key Laboratory of Agro-Environment in the Tropics, Ministry of Agriculture and Rural Affairs, \\ Guangzhou 510642, China \\ * Correspondence: jeanzh@scau.edu.cn; Tel.: +86-20-8528-5505
}

Received: 31 July 2020; Accepted: 24 September 2020; Published: 3 October 2020

check for updates

\begin{abstract}
Acid rain has become one of the major global environmental problems, and some researches reported that acid rain may have a certain inhibition on soil biodiversity. Besides this, it is well known that earthworm (Eisenia fetida) plays an important role in the functioning of soil ecosystems. For this point, we conducted a series of experiments to investigate whether acid rain would take effects on earthworms. In the present study, the earthworms were incubated on filter paper and in soil under acid rain stress. The mortality and behavior of earthworms were recorded, and epidermal damage and the activity of the CYP3A4 enzyme were measured for the tested earthworms. Our experimental results showed that the earthworms could not survive in the acid rain stress of pH below 2.5, and acid rain with weak acidity (i.e., $4.0 \leq \mathrm{pH} \leq 5.5$ ) promoted the activity of the CYP3A4 enzyme in the earthworms, while acid rain with strong acidity (i.e., $3.0 \leq \mathrm{pH} \leq 3.5$ ) inhibited it. Moreover, the degree of damage in sensitive parts of the earthworms increased with the decrease of $\mathrm{pH}$ value. This study suggests that acid rain can cause discomfort response and the direct epidermal damage of earthworms, and even kill them.
\end{abstract}

Keywords: earthworm; acid rain; physiological responses; CYP3A4; epidermal damage

\section{Introduction}

In the last decades of the twentieth century, acid rain was identified as one of the most serious environmental problems [1]. For some time, especially in the 1980s, many people thought that acid rain was one of the most serious environmental threats [2]. During that time, through the news media reports, people learned about the degradation of forests on the European Continent and the extinction of fish in Scandinavian surface waters. Not only that, even in North America, people understood the harm of acid rain to the environment. Therefore, acid rain has received more and more attention from the public. Today, acid rain has expanded from industrialized countries to developing countries [3] and has gradually evolved into a worldwide problem [4].

Acid rain is the result of the rapid development of industry and commerce [5,6], and more and more studies have paid attention to the impact of acid rain on ecosystems. For instance, the results of Zhang et al. [7] showed that acid rain at pH 3.5 and $\mathrm{pH} 2.5$ inhibited photosynthesis and antioxidant defense system of tea tree, causing metabolic disorder, and ultimately affected the growth and development of the plants, while the acid rain at $\mathrm{pH} 4.5$ had no toxic effects on tea seedlings. Jin et al. [8] showed that acid rain could significantly reduce the carbon, nitrogen, and phosphorus contents of early 
rice leaves at the jointing stage $(p<0.05)$. Also, Chen et al. [9] indicated that in the whole growing season of early rice, the effect of acid rain on total organic carbon (TOC) content of the soil was not significant $(p<0.05)$. However, in the green and mature period of late rice, the acid rain significantly increased TOC content $(p<0.05)$. Moreover, the content of soil microbial biomass carbon (MBC) in early rice and late rice showed a significant change with time, which showed that the content of MBC in the early rice was lower than those in the acid rain treatment $(p<0.05)$, while for those in the late rice, it was the opposite. Other studies have focused on soil microbes, and there has been a lot of work on the function and structure of litter-decomposing microbial communities under acid rain [10]. In the study, the results presented that the types of litter affected the functions and community composition of microbes, but there was non-significant difference between acid rain treatments. Furthermore, Liu et al. [11] showed that both acid rain of $\mathrm{pH} 4.0$ and $\mathrm{pH} 3.0$ significantly increased the total amount of soil microbial phospholipid fatty acids (PLFAs) by increasing the PLFA contents of gram-positive bacteria, actinomycetes, fungi, and arbuscular mycorrhizal fungi. Most of the existing studies have focused on the impact of acid rain on plants, soil nutrients, and soil microorganisms, but few have focused on the impact of acid rain on soil animals, especially on earthworms. Even though soil animals make only a small direct contribution to the energy flow in terrestrial ecosystems [12], they have a strong indirect effect on energy flow due to the strong influence of litter fragmentation, inoculation, bioturbation, and soil aeration on microbial mineralization and immobilization processes $[13,14]$. Earthworm is one of the most important invertebrates in terrestrial ecosystems [15], it plays not only an irreplaceable role in maintaining the function of the soil ecosystem but also an important bridge to communicate the connection between soil and terrestrial organisms through the food chain [16]. Earthworms have an enrichment effect on most of the pollutants entering the soil [17] and have been recommended by international organizations such as Organization for Economic Co-operation and Development (OECD) and International Organization for Standardization (ISO) as important indicator organisms for ecological risk assessment of toxic substances in terrestrial environments [18-20]. Recently, some studies have shown that soil pollution [21-23] and acid rain [24,25] are severe in Southern China. Therefore, it is of great significance to investigate whether and how acid rain will influence earthworms in this area. The previous study showed that, due to acid toxicity, earthworms tried to stay away from the soil and died due to acid rain at $\mathrm{pH}=2.0$, and the activity of catalase in the earthworms decreased with the increase of $\mathrm{pH}$ value of acid rain, while the activity of superoxide dismutase showed a fluctuating pattern [26]. Therefore, this study will further evaluate the possible harm of acid rain to earthworms. The aim is to explain the toxic effects of acid rain on earthworms through external morphological changes and internal enzyme changes.

Certain pollutants in the environment can induce or inhibit CYP (Cytochrome P450), resulting in changes in enzyme activity, which in turn affects the metabolism of itself and other substances. CYP3A4 is one of the most important sub-enzymes in CYP450, and it is involved in the metabolism of more than 150 drugs (about 50\% of all drugs) in about 38 categories [27]. In particular, it has a special indicative effect on endocrine disruptors [28-30]. Therefore, the activity of the CYP3A4 enzyme can be used as a potentially sensitive biomarker for the toxicological diagnosis of pollutants in soil. Besides this, it is of great significance to accurately evaluate the response relationship between CYP3A4 enzyme activity and pollutants for the ecotoxicological study of environmental pollution.

In this study, based on the situation of acid rain in Guangzhou, China, we investigated the effect of acid rain on Eisenia fetida. The short-term filter paper experiment $(72 \mathrm{~h})$ and soil experiment (15 days) were used to clarify the physiological responses of the earthworms, and the activity of the CYP3A4 enzyme in the earthworms under acid rain stress (with a pH of 2.0, 2.5, 3.0, 3.5, 4.0, 4.5, 5.0, 5.5, 7.0) was studied. We hypothesized that acid rain would cause adverse effects on the earthworms by damaging the epidermis and changing physiological characteristics, such as the activity of the CYP3A4 enzyme. This study would provide a reference for clarifying the physiological and ecological changes of soil organisms in response to acid rain stress. 


\section{Materials and Methods}

\subsection{Experimental Device}

The soil column for the test was divided into two parts. The upper part was the leaching device and the lower part was the collection device. The leaching device was made of PVC pipe $(\mathrm{d}=7 \mathrm{~cm}, \mathrm{~h}=20 \mathrm{~cm})$, and the filling order from top to bottom was plastic plate, $0.05 \mathrm{~mm}$ nylon mesh, filter paper, inert quartz sand with a thickness of about $10 \mathrm{~mm}, 0.05 \mathrm{~mm}$ aperture nylon mesh, soil with a height of about $15 \mathrm{~cm}$, and $0.05 \mathrm{~mm}$ nylon mesh (Figure 1). Nylon mesh and quartz sand were used to make the leaching as uniform as possible. The entire leaching device was placed on a multi-hole support frame until the end of the experiment. The top-down order of the collection device was funnel and brown glass bottle and placed in the multi-hole support frame.

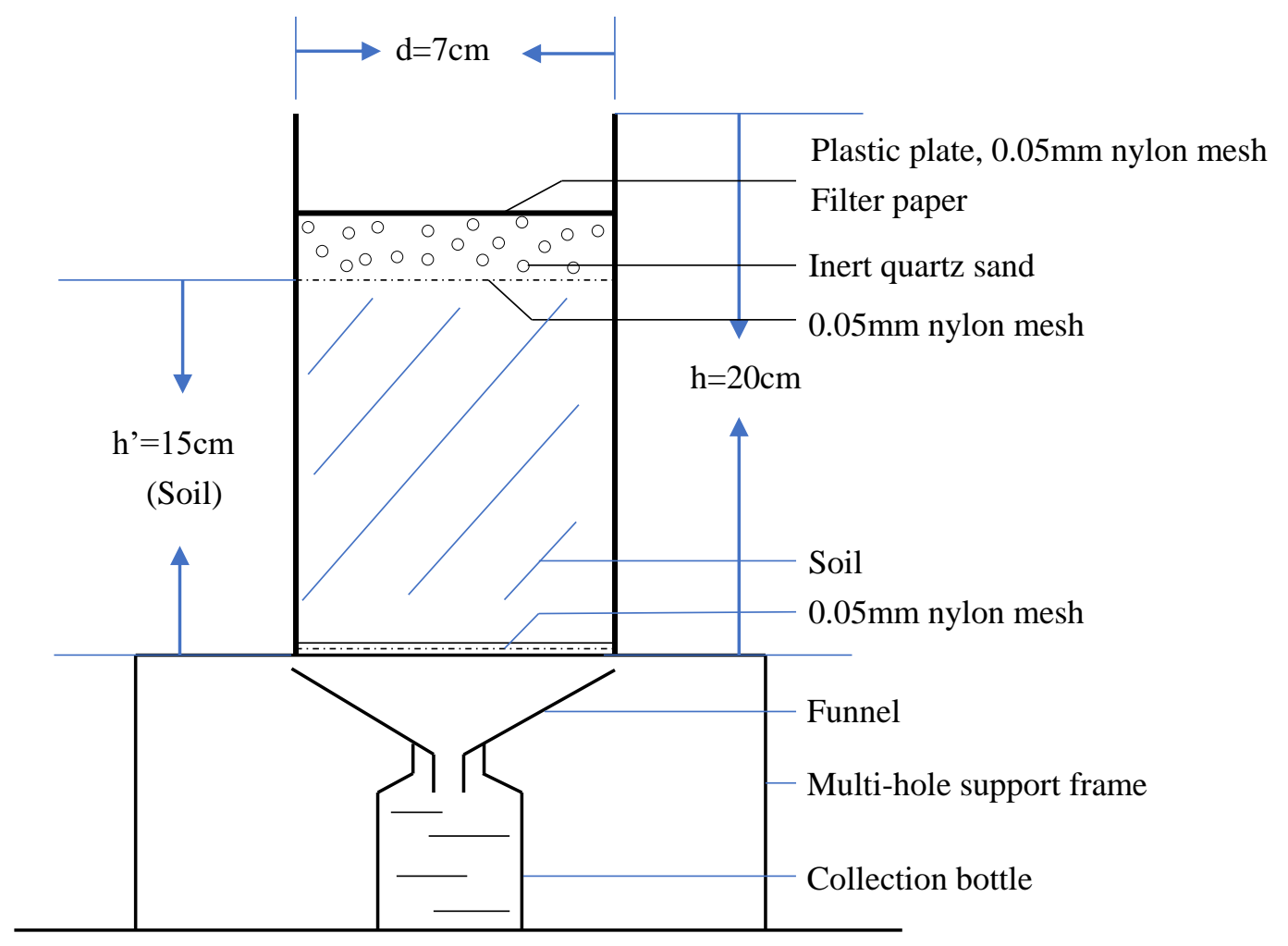

Figure 1. Schematic diagram of the constructed soil column.

\subsection{Tested Materials}

\subsubsection{Preparation of Acid Rain}

According to the characteristics of acid rain in Guangzhou, mother liquor $(\mathrm{pH}=1.0)$ for the simulated acid rain was prepared with the molar ratio of sulfate to nitrate at 5:1 [31], and it was sealed and stored for reserve. Then, the mother liquor was used to dilute into leaching solutions with $\mathrm{pH}$ values of 2.0, 2.5, 3.0, 3.5, 4.0, 4.5, 5.0, and 5.5, respectively. Deionized water $(\mathrm{pH}=7.0)$ was set as the control. In this experiment, as standard catalog items, analytical grade sulfuric acid $\left(\mathrm{H}_{2} \mathrm{SO}_{4}\right)$ and nitric acid $\left(\mathrm{HNO}_{3}\right)$ were purchased from Guangzhou Chemical Reagent Manufacture Inc., China.

\subsubsection{Tested Earthworm}

The earthworm used in the experiment was Eisenia fetida, provided by the Department of Soil Science, College of Natural Resources and Environment, South China Agricultural University, China. Healthy adult earthworms with clitella were selected at the age of 2 to 3 months, with a weight of 
200 to $500 \mathrm{mg}$. Before the experiment, the earthworms were pre-cultured in clean soil for 7 days to adapt to the tested soil environment.

\subsubsection{Tested Soil}

The experimental latosol was taken to a depth of $20 \mathrm{~cm}$ from a forest garden located on the campus of South China Agricultural University, Guangdong Province, China. In this work, the air-dried soil was crushed and sieved after passing through the sieve of 2-mm mesh, which had a $\mathrm{pH}$ of 4.3, an organic matter content of $44.87 \mathrm{~g} \cdot \mathrm{kg}^{-1}$, a base saturation of $13.1 \%$, and a cation exchange capacity of $6.70 \mathrm{mmol} \cdot \mathrm{kg}^{-1}$. Furthermore, the initial contents of soil cation, including $\mathrm{H}^{+}, \mathrm{Ca}^{2+}, \mathrm{Na}^{+}, \mathrm{Al}^{3+}, \mathrm{K}^{+}$, and $\mathrm{Mg}^{2+}$, were $0.378,0.781,0.048,3.211,0.072$, and $0.0683 \mathrm{cmol} \cdot \mathrm{kg}^{-1}$, respectively.

\subsection{Experimental Design}

\subsubsection{Exposure Experiments}

In this study, the earthworms were incubated on filter paper and in soil under acid rain stress.

In the filter paper test, the bottom diameter of the beaker was $2.4 \mathrm{~cm}$ and the height was $15 \mathrm{~cm}$. A layer of filter paper was put at the bottom of the beaker, the earthworms were placed on the paper, then $3 \mathrm{~mL}$ of acid rain was applied to them. The beaker was sealed with a plastic film with pinholes and then placed in an incubator (Hadonglian HPG-280BX) at $20 \pm 2$ degrees ${ }^{\circ} \mathrm{C}$ to avoid light. This test consisted of 9 treatments, which refer to different $\mathrm{pH}$ values respectively, each treatment had 10 replications and each repetition contained an earthworm. Furthermore, the entire experiment lasted $72 \mathrm{~h}$.

In the soil test, $0.5 \mathrm{~kg}$ of air-dried soil was filled into each soil column, and the soil columns were placed in pure water for $48 \mathrm{~h}$, then removed and stood still for $72 \mathrm{~h}$. Based on the average annual precipitation in Guangdong in $2018(1843 \mathrm{~mm}), 30 \%$ of the annual precipitation was selected as the surface runoff [32], and the total leaching volume was determined to be $4.97 \mathrm{~L}$. In this study, an intermittent leaching method was used, and $994 \mathrm{~mL}$ simulated acid rain leached into the column at one time. Controlling the flow rate with a peristaltic pump of $0.35 \mathrm{~mL} \cdot \mathrm{min}^{-1}$, leaching every $72 \mathrm{~h}$, a total of 5 times. Therefore, the cumulative leaching amount was equivalent to the local precipitation in 2018. In the test, 10 earthworms treated with jejunum for $24 \mathrm{~h}$ were added to each soil column and cultured in an incubator (Hadonglian HPG-280BX) at $20 \pm 2$ degrees ${ }^{\circ} \mathrm{C}$; for 15 days. This test involved 9 treatments which refer to different $\mathrm{pHs}$ and each $\mathrm{pH}$ treatment was tested in 3 replications with 10 earthworms per soil column. The pathological symptoms and behaviors of the earthworms in two culture experiments were observed and recorded daily, including morphological change, swelling, and activity. When there was no response to the stimulation on the earthworm's tail, this result indicated that the earthworm was dead.

\subsubsection{Measurement of CYP3A4 Enzyme Activity}

After the earthworm was disintegrated, the tissue was extracted. Then the microsomal protein was prepared and incubated in vitro. Using testosterone (Sigma Aldrich (Shanghai) Trading Co., Ltd., Shanghai, China) as probe drug and the activity of the CYP3A4 enzyme was determined by HPLC (Waters 2695) with methanol (Guangzhou Congyuan Instrument Ltd., Guangzhou China)/ultra-pure water $(50 / 50, \mathrm{~V}: \mathrm{V})$ as the mobile phase. The detection wavelength was $254 \mathrm{~nm}$ and the flow rate was $1.5 \mathrm{~mL} \cdot \mathrm{min}^{-1}$. Furthermore, the retention time of $6 \beta$-hydroxytestosterone was $2 \mathrm{~min}$ [33-35].

\subsubsection{Scanning of the Electron Microscope of Earthworm Epidermis}

At first, the samples were fixed with glutaraldehyde Fixation for $8 \mathrm{~h}$. Secondly, they were soaked in 50\% ethanol, $70 \%$ ethanol, $85 \%$ ethanol, $95 \%$ ethanol, and $100 \%$ ethanol respectively for $14 \mathrm{~min}$, $14 \mathrm{~min}, 14 \mathrm{~min}, 15 \mathrm{~min}$, and $15 \mathrm{~min}$. Glutaraldehyde and ethanol were purchased from Guangzhou Congyuan Instrument Ltd., China. Thirdly, we freeze-dried the above treated samples for $3 \mathrm{~h}$, then used double-sided conductive glue to stick the samples on the observation platforms and sprayed gold. 
Finally, we observed and took photos of the samples under the scanning electron microscope (Hitachi S-3400N) (HITACHI, Tokyo, Japan) [36].

\subsection{Statistical Analysis}

At first, the pathological symptoms and behavior of earthworms were recorded in a report on the number of observed effects. Second, Microsoft Office Excel 2007 (Microsoft Corporation, Redmond, WA, USA) was used for the data collection of the activity of the CYP3A4 enzyme, and the results were shown as means \pm standard error. Third, SPSS 17.0 (IBM, Chicago, IL, USA) was used for statistical analysis, and all the data of the activity of the CYP3A4 enzyme were compared by Duncan's method for significance at a significance level of 5\%. Fourth, Origin 8.0 (OriginLab, Northampton, MA, USA) was used for graphing.

\section{Results and Discussion}

\subsection{Behavior and Mortality of Earthworms}

Compared with the control (Figure 2), when exposed for $0.5 \mathrm{~h}$ in the filter paper experiments, the earthworms at $\mathrm{pH} 2.0$ showed ring swelling and a sugar gourd shape. After $6 \mathrm{~h}$, the earthworms at $\mathrm{pH}$ below 3.0 became sluggish. After $24 \mathrm{~h}$, the earthworms at $\mathrm{pH} 2.0$ appeared broken nodes, and the bodies were soft and eroded from the ring also with exuding yellow liquid, and $40 \%$ of the earthworms died. At the same time, $70 \%$ of the earthworms at $\mathrm{pH} 2.5$ showed symptoms of poisoning with curling and bending. After $48 \mathrm{~h}$, all the earthworms died at $\mathrm{pH} 2.0$, and at $\mathrm{pH} 2.5,50 \%$ of the earthworms exuded yellow liquid. After $72 \mathrm{~h}$, the earthworms at $\mathrm{pH} 2.5$ appeared broken nodes, and their bodies became soft and eroded from the ring, and $40 \%$ of the earthworms died. Meanwhile, $30 \%$ of the earthworms at $\mathrm{pH} 3.0$ and $20 \%$ of the earthworms at $\mathrm{pH} 3.5$ had yellow liquid exudation. Besides this, $60 \%$ and $40 \%$ of the earthworms elongated at $\mathrm{pH} 4.0$ and $\mathrm{pH} 4.5$, respectively. During the whole experiment period, the earthworms at $\mathrm{pH} 5.0$ and $\mathrm{pH} 5.5$ did not show obvious symptoms of acid rain poisoning. At the end of the experiment, the mortality of the earthworms in the treatment group with pH 2.0 was $100 \%$, and that at $\mathrm{pH} 2.5$ was $40 \%$ (Table 1). There was no death appeared in the other groups. 


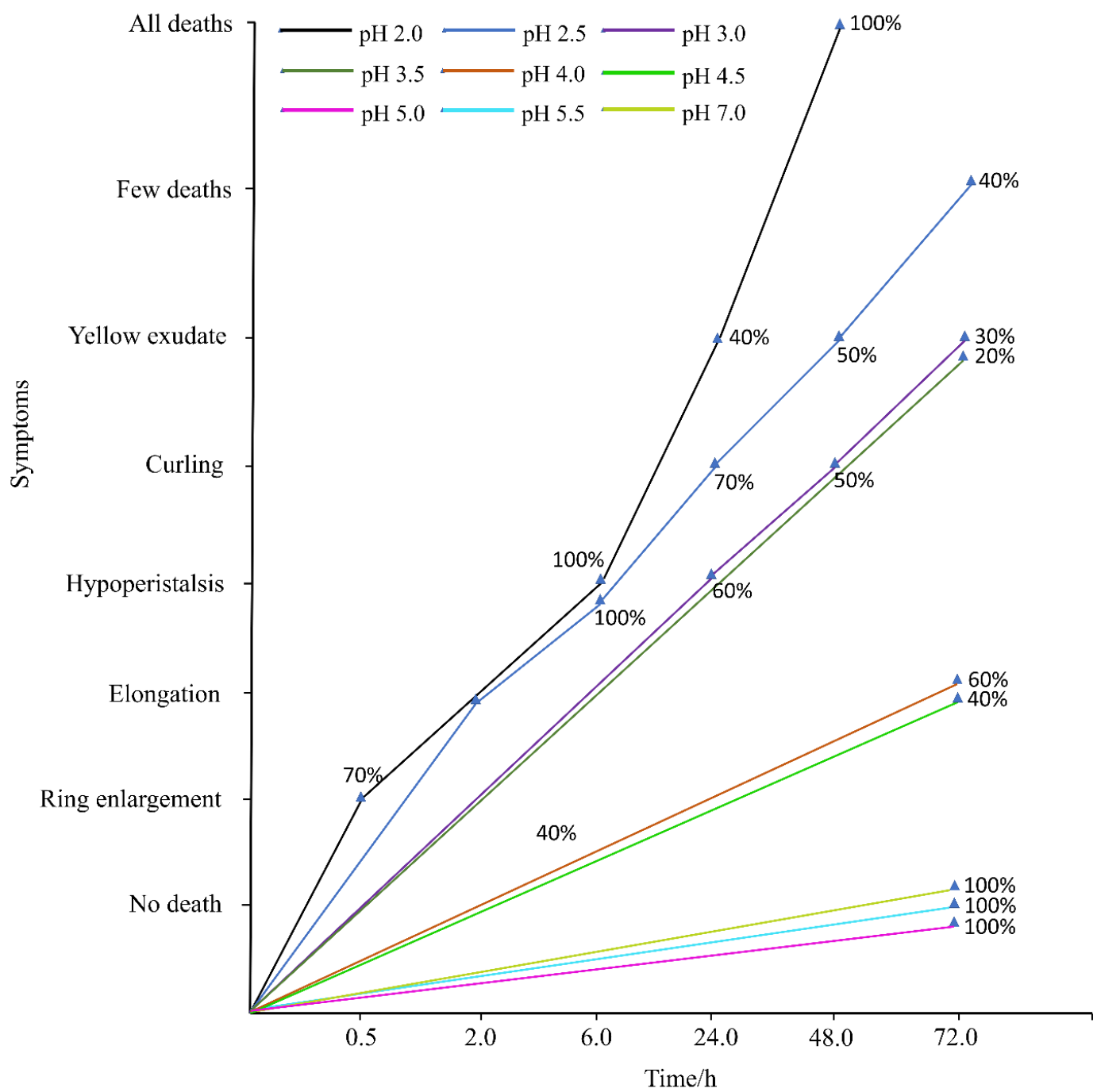

Figure 2. Behavior of adult Eisenia fetida on filter paper under acid rain with eight $\mathrm{pH}$ levels for $72 \mathrm{~h}$ $(n=10)$. Treatments: $\mathrm{pH} 7.0$ : control, $\mathrm{pH}$ 2.0-5.5: acid rain with different $\mathrm{pH}$ values. Percentages indicate the number of earthworms with the symptom.

Table 1. Accumulative mortality of adult Eisenia fetida on filter paper under acid rain with eight $\mathrm{pH}$ levels for $72 \mathrm{~h}(n=10)$. Treatments: $\mathrm{pH} 7.0$ : control, $\mathrm{pH}$ 2.0-5.5: acid rain with different $\mathrm{pH}$ values.

\begin{tabular}{cc}
\hline $\mathbf{p H}$ & Accumulative Mortality Rate (\%) \\
\hline 2.0 & 100 \\
2.5 & 40 \\
3.0 & 0 \\
3.5 & 0 \\
4.0 & 0 \\
4.5 & 0 \\
5.0 & 0 \\
5.5 & 0 \\
7.0 & 0 \\
\hline
\end{tabular}

The results of the soil test were consistent with those of the filter paper test (Figure 3). During the 15-day test period, the earthworms between $\mathrm{pH} 5.0$ and 5.5 survived well without symptoms of acid rain poisoning. Compared with the control, $60 \%$ of the earthworms at $\mathrm{pH} 2.0$ appeared the symptoms on the surface of the soil and tended to escape from the soil columns on the third day. After 7 days of leaching experiments, the earthworms in the treatment group with $\mathrm{pH}$ less than 5.0 wriggled 
slowly. After 15 days of acid rain treatment, the earthworms between $\mathrm{pH} 2.0$ and $\mathrm{pH} 3.5$ exuded yellow liquid and all the earthworms at $\mathrm{pH} 2.0$ died on the surface of the soil. Furthermore, the surface of earthworms at $\mathrm{pH} 2.5$ lost luster, the color became dark, and $20 \%$ of them died. In this experiment, the mortality of the earthworms in the acid rain treatment at $\mathrm{pH} 2.0$ was $100 \%$, and that at $\mathrm{pH} 2.5$ was $20 \%$ (Table 2). But there was no death in the other groups.

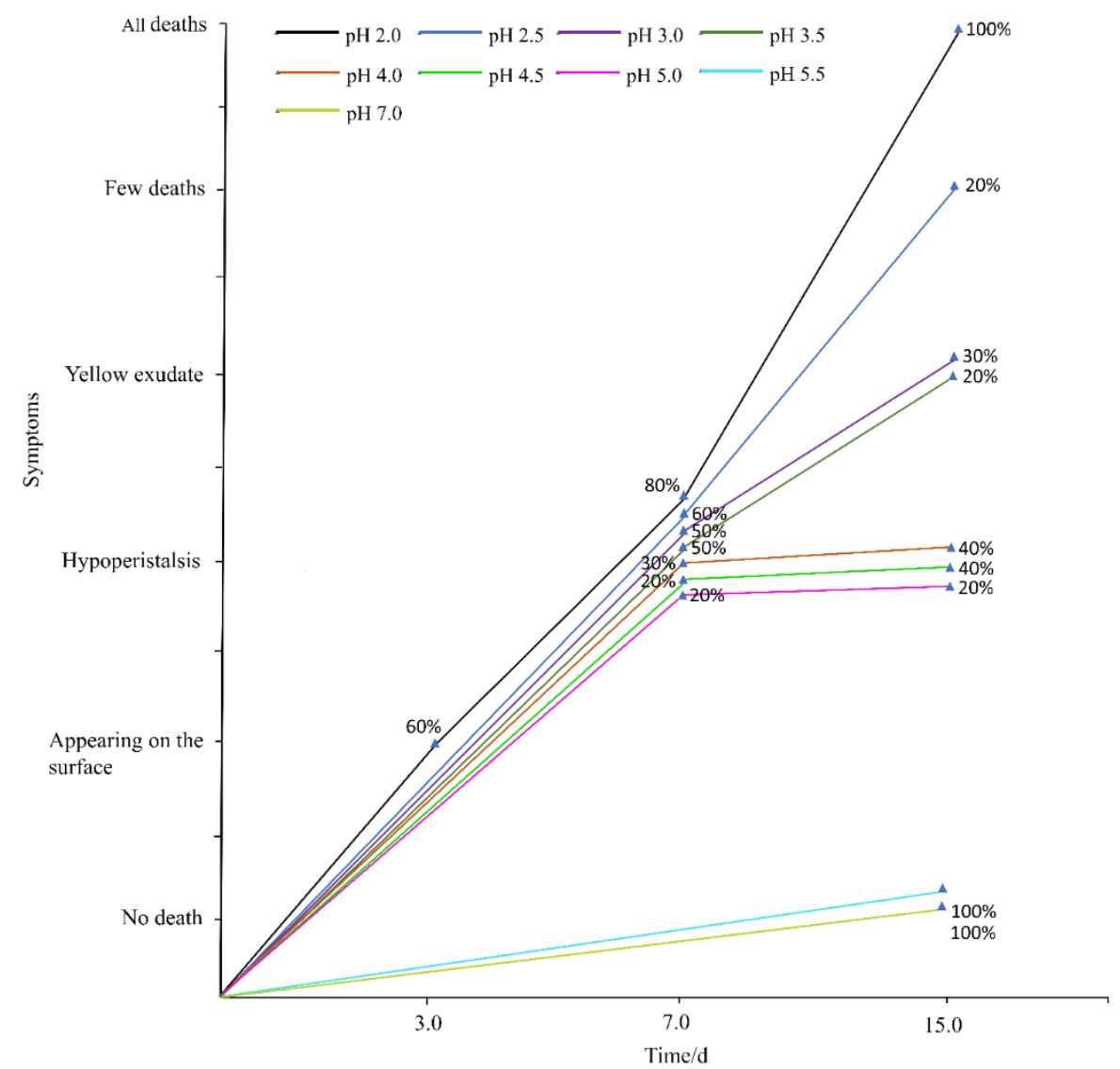

Figure 3. Behavior of adult Eisenia fetida in soil under acid rain with eight $\mathrm{pH}$ levels for 15 days $(n=10)$. Treatments: $\mathrm{pH}$ 7.0: control, $\mathrm{pH}$ 2.0-5.5: acid rain with different $\mathrm{pH}$ values. Percentages indicate the number of earthworms with the symptom.

Table 2. Accumulative mortality of adult Eisenia fetida in soil under acid rain with eight $\mathrm{pH}$ levels for 15 days $(n=10)$. Treatments: $\mathrm{pH}$ 7.0: control, $\mathrm{pH}$ 2.0-5.5: acid rain with different $\mathrm{pH}$ values.

\begin{tabular}{cc}
\hline $\mathbf{p H}$ & Accumulative Mortality Rate $\mathbf{( \% )}$ \\
\hline 2.0 & 100 \\
2.5 & 20 \\
3.0 & 0 \\
3.5 & 0 \\
4.0 & 0 \\
4.5 & 0 \\
5.0 & 0 \\
5.5 & 0 \\
7.0 & 0 \\
\hline
\end{tabular}

The effects of acid rain on soil animals can be divided into the following two categories. One is that the death caused to soil animals in contact with or deep into the body is called direct impact [35,37]. The other is that the $\mathrm{pH}$ value of the soil is reduced due to the falling and adsorption of acid rain, which is called indirect effect [38]. In the death caused by direct contact and entry into the body, 
sensitive mammals and weakly resistant animals are most affected by acid rain, including nematodes and earthworms $[39,40]$. The filter paper experiments in this study indicated that earthworm was susceptible to acid rain under the experimental conditions. Studies have shown that the adverse effect of acid rain on the growth of earthworms increases with the decrease of $\mathrm{pH}$ value of acid rain [41], which may be that $\mathrm{H}^{+}$in acid rain reduces the $\mathrm{pH}$ value of cells and changes the normal $\mathrm{pH}$ required for life activities such as earthworm growth, development, and reproduction [42].

When acid rain enters into the soil, on one hand, $\mathrm{SO}_{4}{ }^{2-}$ and $\mathrm{NO}^{3-}$ in acid rain cause the decrease of soil $\mathrm{pH}$ and salt-based saturation, while carrying a certain amount of cations away from the soil, resulting in the leaching of salt-based ions $\left(\mathrm{K}^{+}, \mathrm{Na}^{+}, \mathrm{Ca}^{2+}, \mathrm{Mg}^{2+}, \mathrm{NH}^{4+}\right)$, which exacerbates the process of soil acidification and thus affects the activity of earthworms $[43,44]$. On the other hand, acid rain promotes the release of heavy metals in soil and improves its bioavailability [44]. Although earthworms have a certain tolerance limit to heavy metals when the content of heavy metals exceeds the limit, heavy metals will produce toxic effects, and then affect the normal physiological function of earthworms [45]. Reinecke et al. [46] found that $\mathrm{Pb}$-contamination had no significant effect on the cocoon production rate of earthworms, but had a significant impact on its viability. Salminen et al. [47] studied the resistance of Cognettia sphagnetorum to $\mathrm{Cu}$ and found that the sizes of adults were smaller in the polluted plots. Furthermore, heavy metal contamination can damage the microstructure of cells, make the activity of enzymes abnormal, and affect the repair ability of DNA. Guo et al. [48] and Wang et al. [49] also reported that heavy metals could cause severe damage to the epidermis, gastrointestinal tract, and cell microstructure of earthworm.

\subsection{The Epidermal Damage of Earthworms}

In view of the above point regarding the damage of earthworms, the sensitive parts of earthworms (prostomium, ventral surface of reproductive ring, anus) were scanned by an electron microscope. The results showed that in the control, the texture of the prostomium of the earthworms was clear, the epidermis was smooth and elastic, the ventral surface of reproductive rings was clear and evenly distributed, and anal hair was attached to the anus. In the present study, we found that the results of filter paper experiments and soil experiments were consistent (Figure 4, Figure 5, Figures 6-11). That is, the degree of damage in sensitive parts (prostomium, epidermis of the first segment, ventral surface of reproductive ring, anus) of earthworms in both culture experiments increased with the decrease of treatment $\mathrm{pH}$. When $\mathrm{pH} \leq 5.5$, the anal hairs of earthworms in both cultures decreased significantly, and the stria on the epidermis of the first segment of earthworms in the soil disappeared obviously. The same symptoms also occurred in the filter paper experiments when $\mathrm{pH} \leq 4.5$. When $\mathrm{pH} \leq 4.0$, the anus of earthworms swelled in both culture experiments. In addition, when $\mathrm{pH} \leq 3.5$, ulcerous foci appeared in the prostomium of earthworms on the filter paper and in the anus of earthworms in the soil. Besides this, the texture on the ventral surface of the reproductive ring of the earthworms in the two cultures was blurred by swelling only in extremely strong acid rain (i.e., $\mathrm{pH}=2.5$ ).

$\mathrm{Li}$ et al. [50] reported that the cells would swell and thicken with water at acidic $\mathrm{pH}$, the contact area and volume would increase, and even the cell membrane would be broken under the strong acidic condition. This is consistent with the results in this study, so it may be one of the reasons for the occurrence of ulcerous foci in earthworms. Other studies suggested that acid rain increases the risk of heavy metal contamination in soil [43]. Wan et al. [3] studied the effects of simulated acid rain on the release of aluminum ion in the soil and the results showed that the $\mathrm{pH}$ of the solution affected the aluminum content in the soil leaching solution, and with the decrease of the acid rain $\mathrm{pH}$, the aluminum content in the leaching solution increased. In addition, the longer the bath time of the same $\mathrm{pH}$ solution, the greater the concentration of aluminum ion in the leaching solution. Another study suggested that when soil $\mathrm{pH}$ was less than 5.0, the dissolution concentration of active aluminum increased significantly and sharply with the decrease of $\mathrm{pH}$ [51]. When heavy metals in soil reach a certain amount, it can cause ulcers and tumors on the surface of earthworms [48]. 


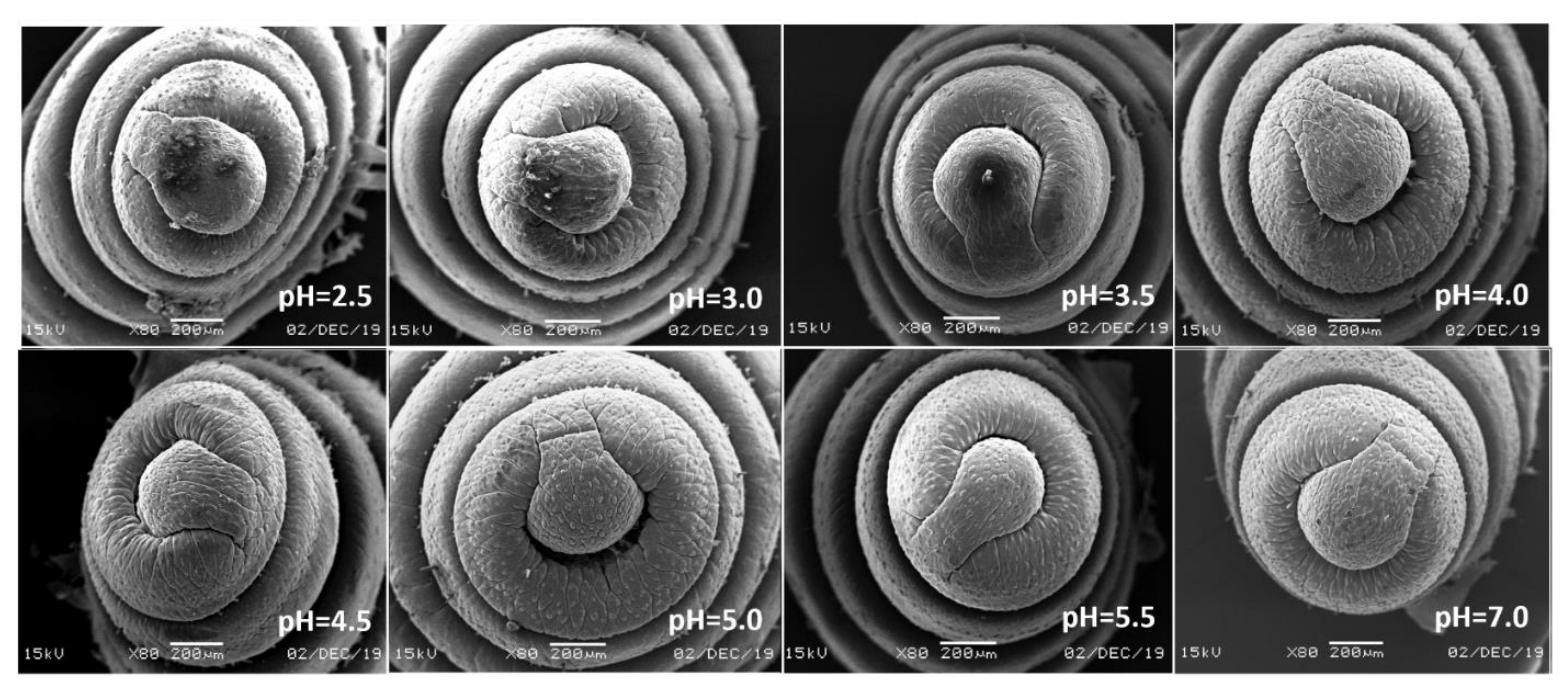

Figure 4. Prostomium of adult Eisenia fetida on filter paper under acid rain with eight $\mathrm{pH}$ levels for $72 \mathrm{~h}(n=10)$. Treatments: $\mathrm{pH}$ 7.0: control, $\mathrm{pH}$ 2.0-5.5: acid rain with different $\mathrm{pH}$ levels.

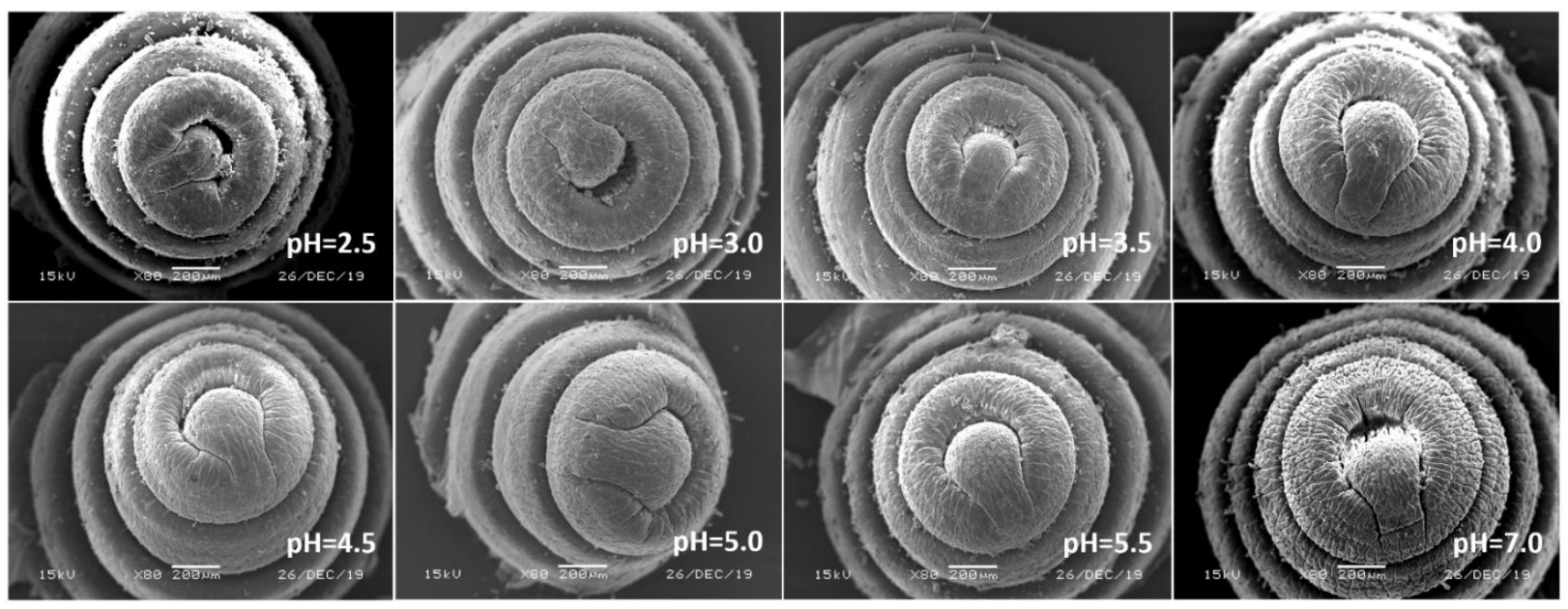

Figure 5. Prostomium of adult Eisenia fetida in soil under acid rain with eight $\mathrm{pH}$ levels for 15 days $(n=10)$. Treatments: $\mathrm{pH}$ 7.0: control, $\mathrm{pH}$ 2.0-5.5: acid rain with different $\mathrm{pH}$ levels. 


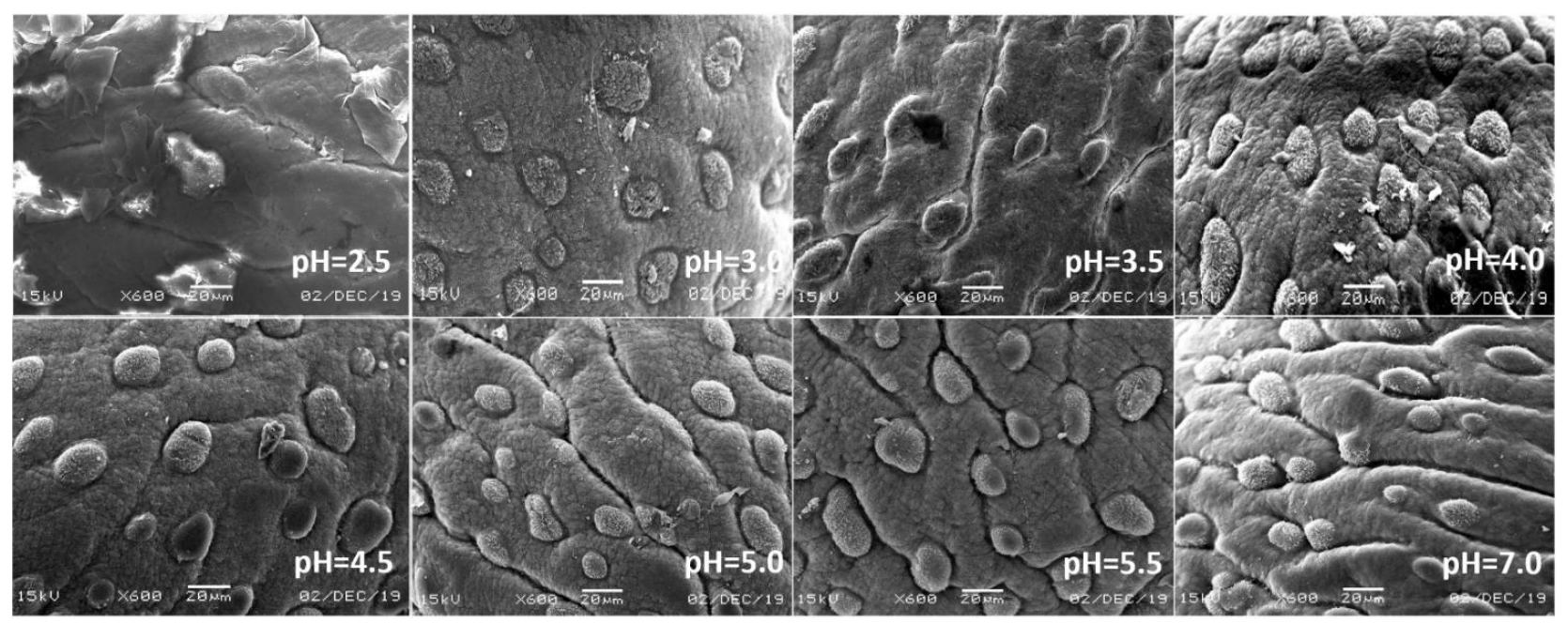

Figure 6. Epidermis of the first segment of adult Eisenia fetida on filter paper under acid rain with eight $\mathrm{pH}$ levels for $72 \mathrm{~h}(n=10)$. Treatments: $\mathrm{pH} 7.0$ : control, $\mathrm{pH}$ 2.0-5.5: acid rain with different $\mathrm{pH}$ levels.

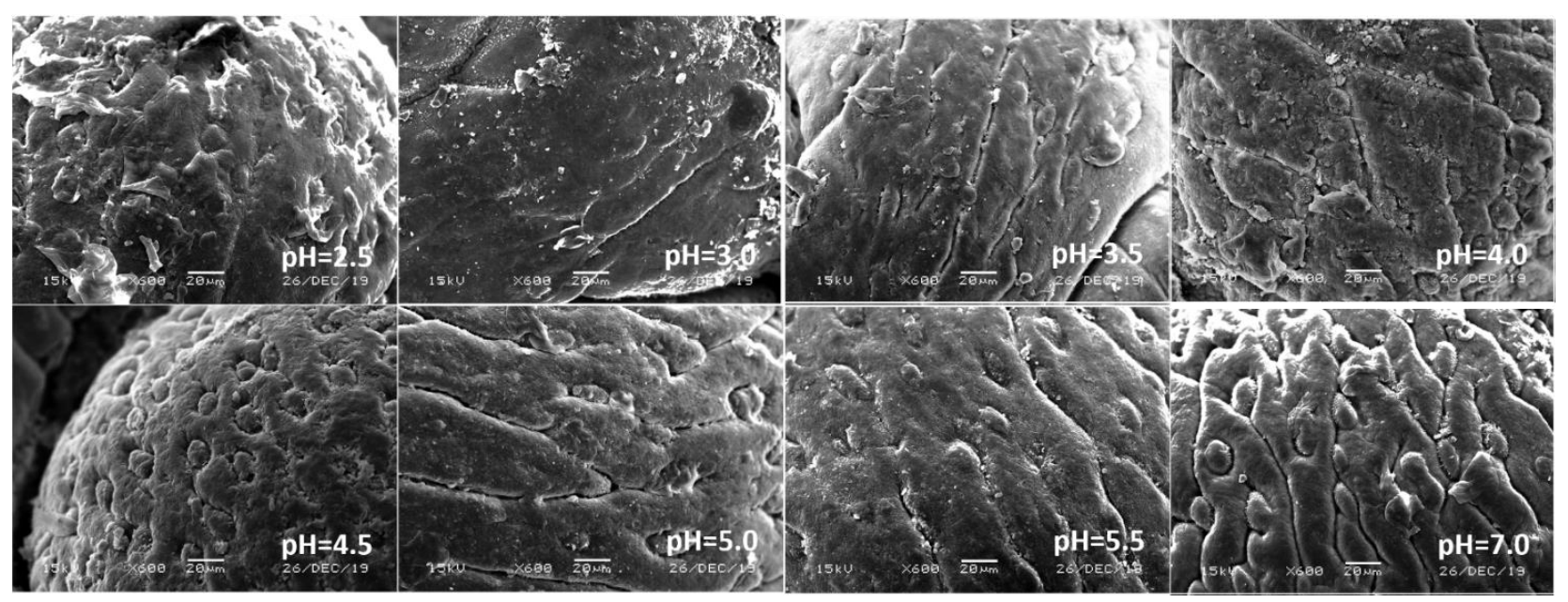

Figure 7. Epidermis of the first segment of adult Eisenia fetida in soil under acid rain with eight $\mathrm{pH}$ levels for 15 days $(n=10)$. Treatments: $\mathrm{pH} 7.0$ : control, $\mathrm{pH}$ 2.0-5.5: acid rain with different $\mathrm{pH}$ levels. 


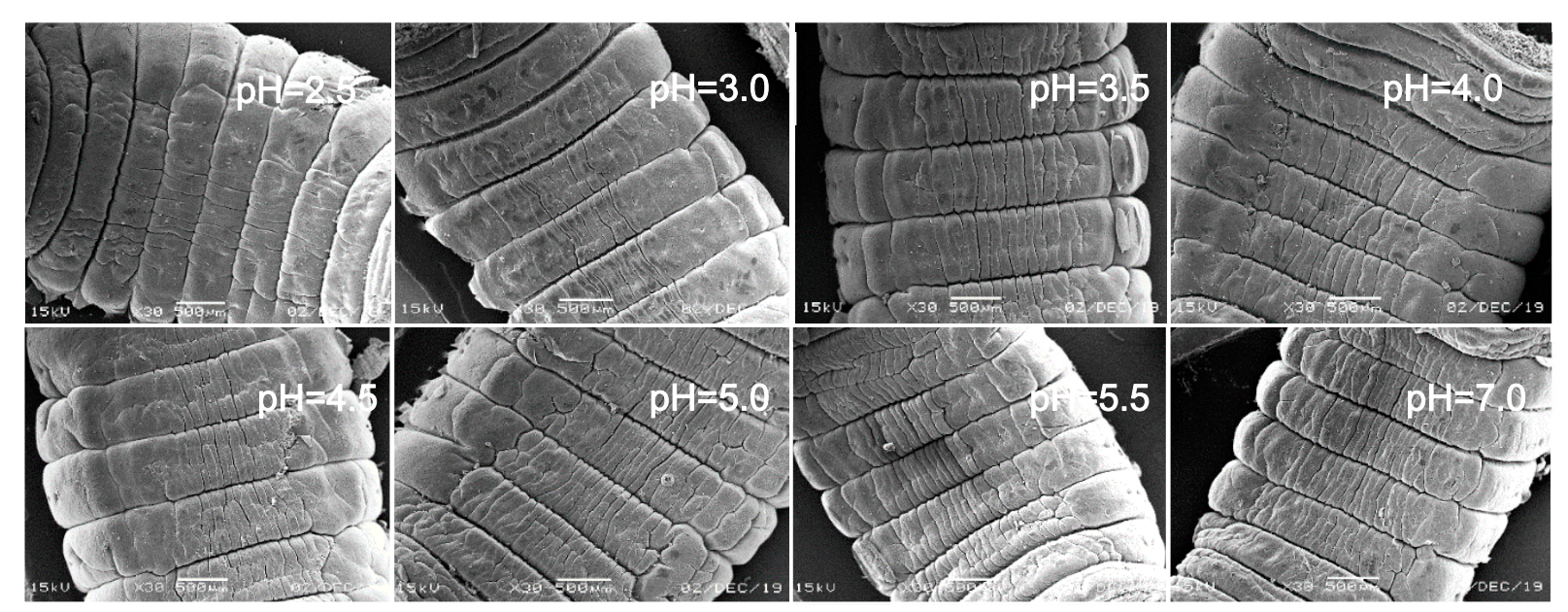

Figure 8. Ventral surface of the reproductive ring of adult Eisenia fetida on filter paper under acid rain with eight $\mathrm{pH}$ levels for $72 \mathrm{~h}(n=10)$. Treatments: $\mathrm{pH} 7.0$ : control, $\mathrm{pH}$ 2.0-5.5: acid rain with different $\mathrm{pH}$ levels.

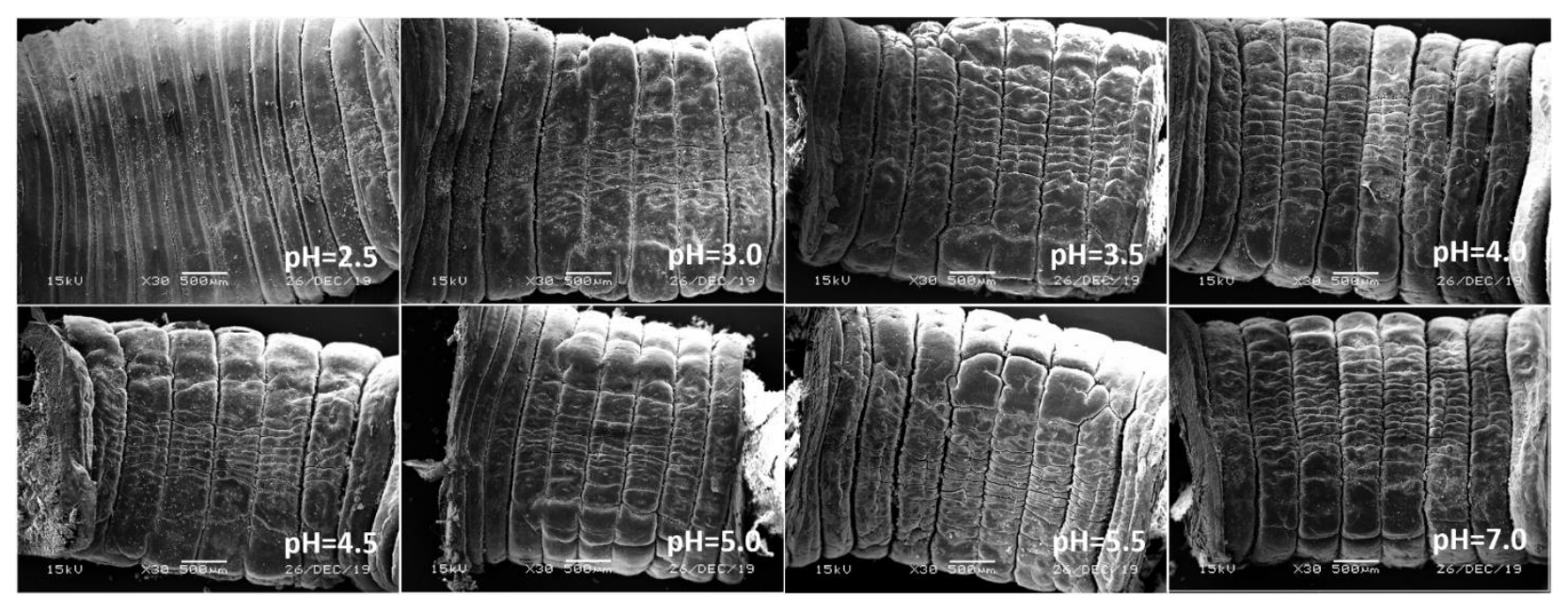

Figure 9. Ventral surface of the reproductive ring of adult Eisenia fetida in soil under acid rain with eight $\mathrm{pH}$ levels for 15 days $(n=10)$. Treatments: $\mathrm{pH} 7.0$ : control, pH 2.0-5.5: acid rain with different $\mathrm{pH}$ levels. 


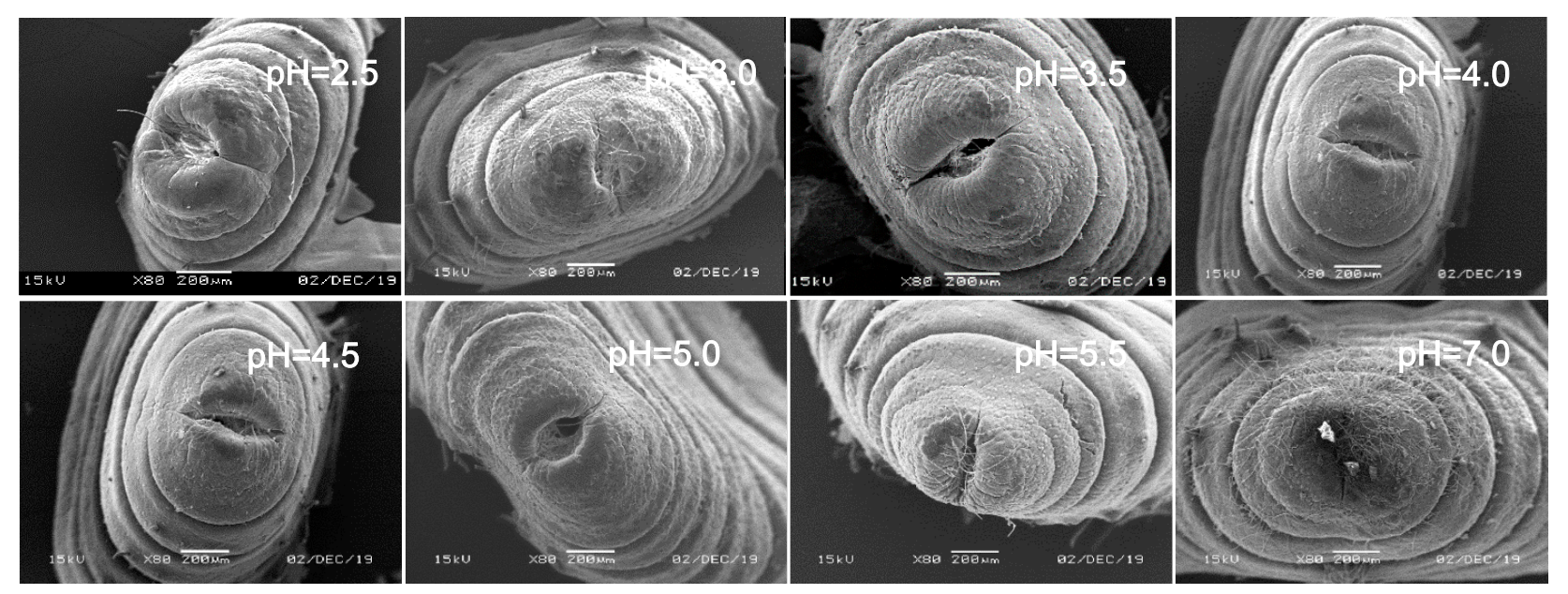

Figure 10. Anus of adult Eisenia fetida on filter paper under acid rain with eight $\mathrm{pH}$ levels for $72 \mathrm{~h}(n=10)$. Treatments: $\mathrm{pH} 7.0$ : control, $\mathrm{pH}$ 2.0-5.5: acid rain with different $\mathrm{pH}$ levels.

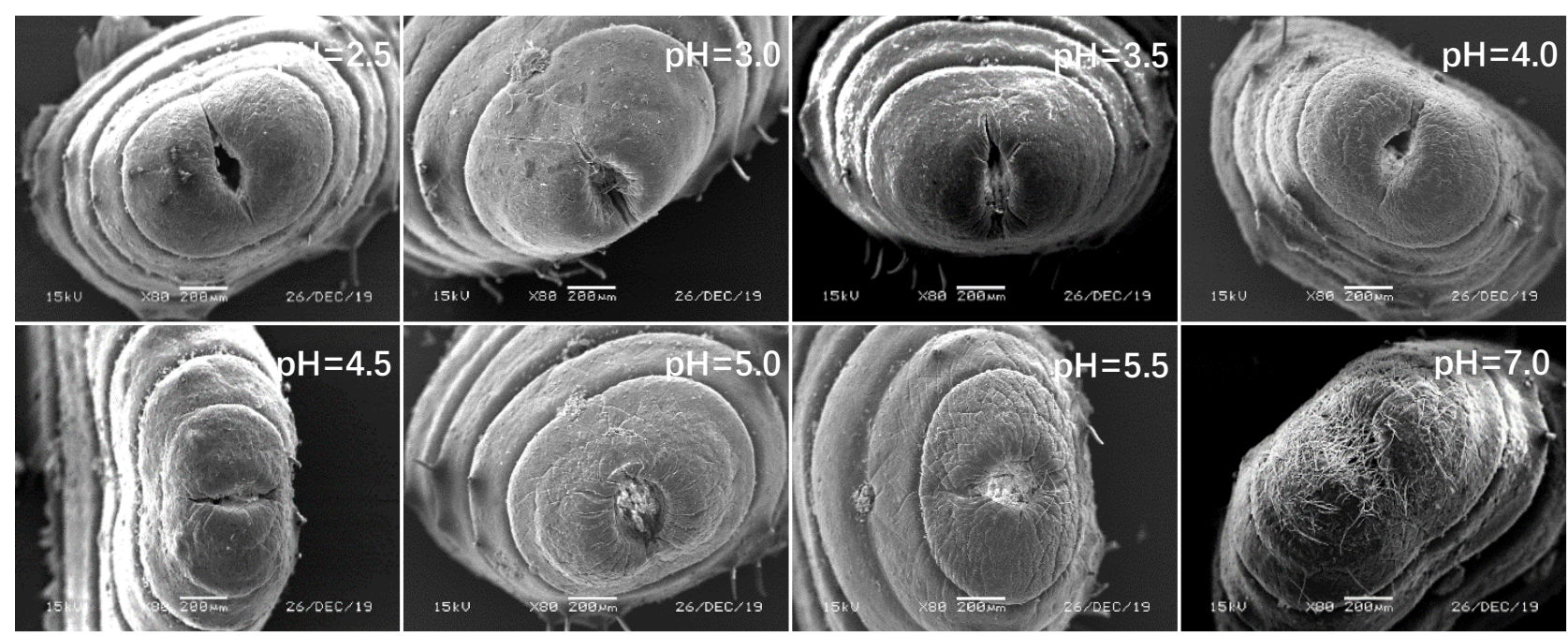

Figure 11. Anus of adult Eisenia fetida in soil under acid rain with eight $\mathrm{pH}$ levels for 15 days $(n=10)$. Treatments: $\mathrm{pH}$ 7.0: control, $\mathrm{pH}$ 2.0-5.5: acid rain with different pH levels. 


\subsection{CYP3A4 Enzyme Activity in Earthworms}

Based on the external performances of earthworms under acid rain stress, we further studied the activity of the CYP3A4 enzyme of the treated earthworms. Cytochrome P4503A4 enzyme (i.e., CYP3A4) is an important enzyme that mainly exists in liver and small intestine. It can oxidize exogenous organic small molecules (heterotypic biomass), such as toxins or drugs so that they can be discharged from the body of earthworm.

In this study, in the filter paper experiments, relative to the control, acid rain increased the activity of the CYP3A4 enzyme in the earthworms by $21.3 \%(\mathrm{pH} 3.5), 19.9 \%(\mathrm{pH} 4.0), 36.1 \%(\mathrm{pH} 4.5), 33.3 \%$ ( $\mathrm{pH} 5.0$ ), and $54.3 \%$ ( $\mathrm{pH} 5.5)$, respectively $(p<0.05$ ) (Figure 12), and significantly reduced it by $19.0 \%$ at $\mathrm{pH} 3.0(p<0.05)$. Furthermore, in the soil test, the activity of the CYP3A4 enzyme in the earthworms was also increased by $15.7 \%$ (pH 3.5), $19.3 \%$ ( $\mathrm{pH} 4.0$ ), 24.3\% (pH 4.5), 13.7\% (pH 5.0), and 36.4\% (pH 5.5), respectively $(p<0.05)$ (Figure 13). Meanwhile, at $\mathrm{pH} 3.0$, acid rain had an inhibitory effect on the CYP3A4 enzyme activity and reduced by $33.9 \%(p<0.05)$.

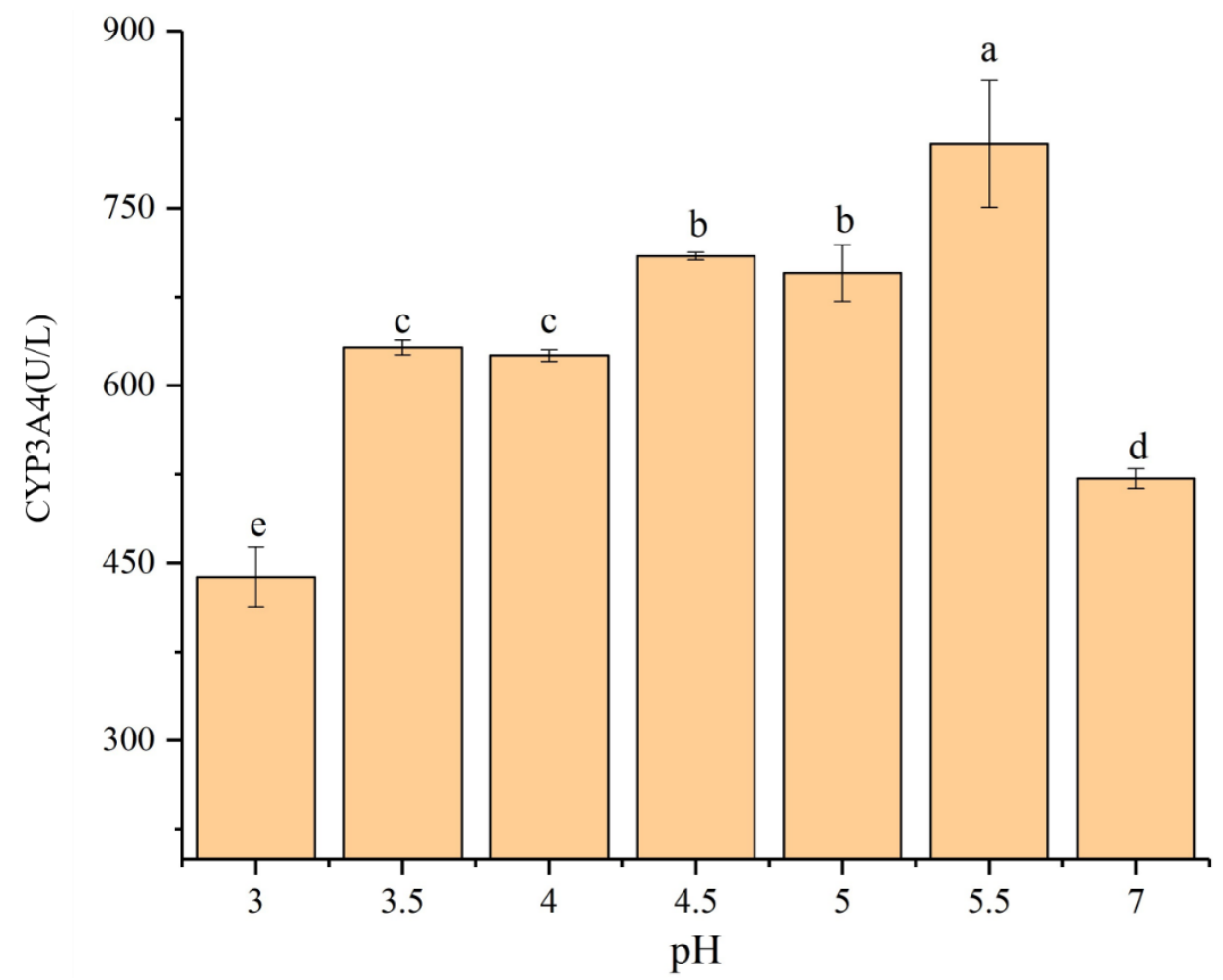

Figure 12. CYP3A4 enzyme activity in adult Eisenia fetida exposed to control filter paper and acid rain contaminated filter paper with eight $\mathrm{pH}$ levels for $72 \mathrm{~h}(n=10)$. Error bars indicate standard error of the means $(n=10)$. Different letters indicate significant difference among treatments $(p<0.05)$.

As can be seen from the results, in a short period, in medium-intensity acid rain treatments (i.e., $3.5 \leq \mathrm{pH} \leq 5.5$ ), the activity of the CYP3A4 enzyme in the earthworms was significantly increased, indicating that acid rain induced its large-scale expression in the earthworms, which proves that the first-phase metabolic enzyme P450 played an important role in metabolism under acid rain stress [36].

Studies have shown that the change of $\mathrm{pH}$ can affect the degree of dissociation of certain groups on the active center of the enzyme, as well as the degree of dissociation of the substrates and coenzymes, thereby affecting the combination and catalysis of the enzyme molecules to the substrate molecules [52]. When the $\mathrm{pH}$ is too low, the enzyme protein will be inactivated due to denaturation [53]. Wang [54] showed that when $\mathrm{pH}<5.0, \mathrm{CYP} 102 \mathrm{~A} 16$ enzyme activity was low and less than $15 \%$ of the enzyme activity under the optimal $\mathrm{pH}$ condition. In this experiment, although the activity of the CYP3A4 enzyme in the earthworms at $\mathrm{pH} 3$ in both culture methods was reduced compared with the control, 
the difference between the soil test and the control was more significant $(p<0.05)$, which may be because, in the filter paper test, $\mathrm{pH}$ is the only factor that affects the activity of the CYP3A4 enzyme, while in the soil test, the soil is a complex ecosystem. When acid rain enters the soil, it can not only directly affect the $\mathrm{pH}$ of soil [55], but also can cause the leaching of salt-based ions, and acid rain with strong acidity can accelerate this process [56]. A previous study has confirmed that excessive salt-based ions can inhibit the activity of the enzyme. Li et al. [57] presented that $1-100 \mathrm{mmol} \cdot \mathrm{L}^{-1} \mathrm{NH}^{4+}, \mathrm{Mg}^{2+}$, $\mathrm{Ca}^{2+}$, and EDTA could inhibit the activity of the CYP102A16 enzyme in varying degrees, among which $\mathrm{Ca}^{2+}$ has the strongest inhibition, and each concentration could inhibit the activity of the CYP102A16 enzyme more than $90 \%$. Plus, acid rain can promote the release of heavy metals in soil, and excessive heavy metals can also inhibit the activity of enzymes [58]. Li et al. [57] showed that the enzyme activity decreased sharply with the increase of metal ion concentration, and in their experiments, $0.2 \mathrm{mmol} \cdot \mathrm{L}^{-1}$ $\mathrm{Zn}^{2+}$ and $1.0 \mathrm{mmol} \cdot \mathrm{L}^{-1} \mathrm{Fe}^{3+}$ could completely inactivate the CYP102A16 enzyme. Therefore, multiple factors in the soil have an inhibitory effect on the activity of the CYP3A4 enzyme in the earthworms.

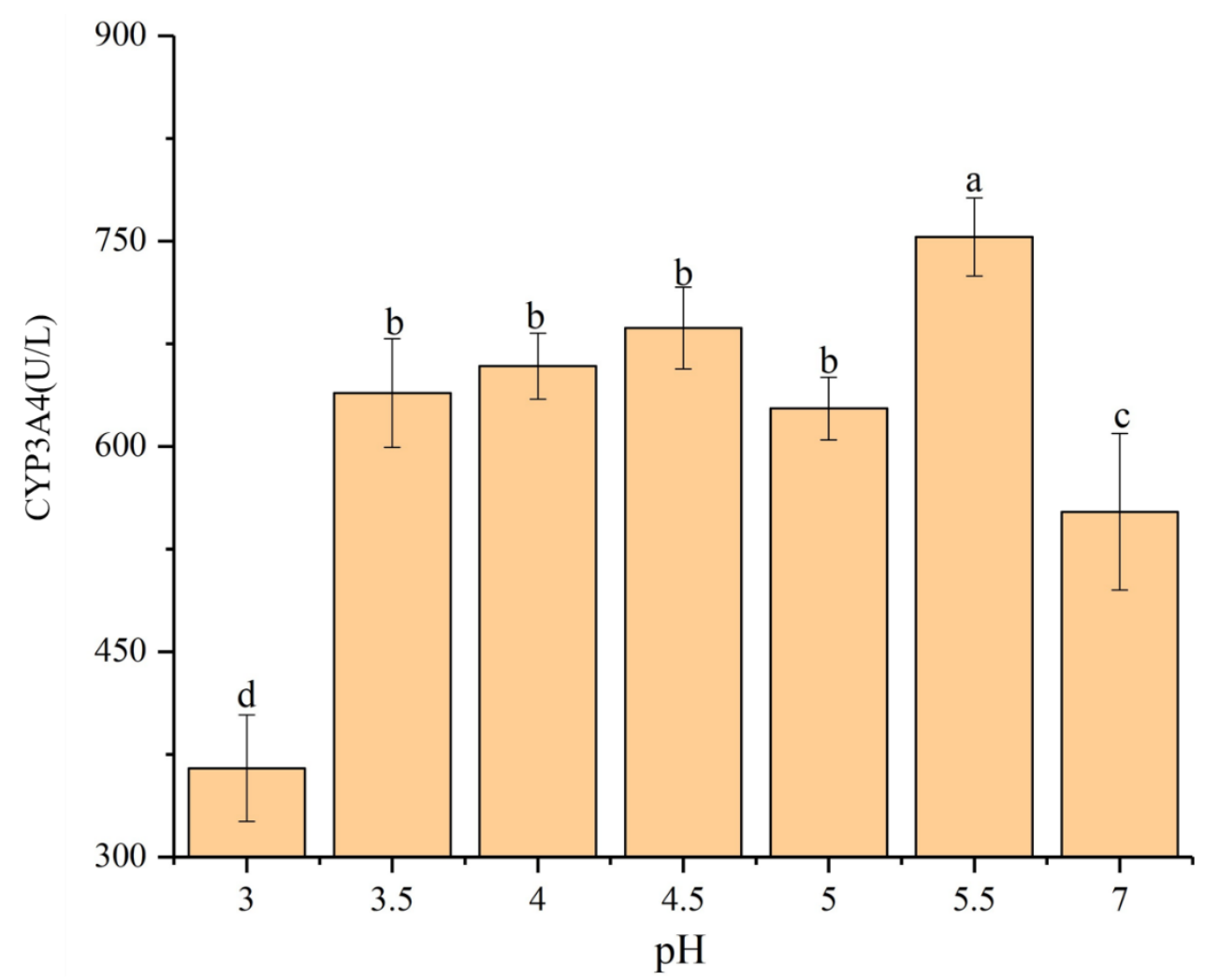

Figure 13. CYP3A4 enzyme activity in adult Eisenia fetida exposed to control soil and acid rain contaminated soil with eight $\mathrm{pH}$ levels for 15 days $(n=10)$. Error bars indicate standard error of the means $(n=10)$. Different letters indicate significant difference among treatments $(p<0.05)$.

\section{Conclusions}

In the present work, the data suggest that acid rain could cause ecotoxicity to the earthworms, even kill them, which only occurred at extremely strong acid rain (i.e., $\mathrm{pH} \leq 2.5$ ). We found that when the acidity of acid rain increased, earthworms gradually showed obvious symptoms of poisoning. Although the earthworms had no obvious pathological symptoms at $\mathrm{pH} 5.5$ of acid rain, the external morphology was still affected. Acid rain could not only cause a stress response of the earthworms but also affect the activity of the CYP3A4 enzyme in the earthworms. It is worth noting that medium-intensity acid rain increased the activity of the CYP3A4 enzyme. The results here further emphasize that the effect of acid rain on the physiological response of earthworms is a complex process. 
Nevertheless, field work is lacking in this study to double confirm acid rain influence on earthworms. As this is a preliminary study for the effects of acid rain on the physiological responses of earthworms under simulated conditions, further research in the natural environment is warranted.

Author Contributions: J.Z. contributed to the conception of the study. X.C. collected and carried out the data analysis, made charts, and wrote the manuscript. H.W. gave constructive help in the discussion. All authors have read and agreed to the published version of the manuscript.

Funding: This research was funded by the National Natural Science Foundation of China (U1701236) and the APC was funded by the Science and Technology Planning Project of Guangdong Province (2019B030301007).

Conflicts of Interest: The authors declare that they have no conflict of interest.

\section{References}

1. Ma, Y.; Wang, B.; Zhang, R.; Gao, Y.; Zhang, X.; Li, Y.; Zuo, Z. Initial simulated acid rain impacts reactive oxygen species metabolism and photosynthetic abilities in Cinnamonum camphora undergoing high temperature. Ind. Crop. Prod. 2019, 135, 352-361. [CrossRef]

2. Haradhan, K.M. Acid rain is a local environmental pollution but global concern. Open Sci. J. Anal. Chem. 2018, 35, 47-55.

3. Wan, Y.S.; Yu, W.M. Analysis on current situation, formation causes and control countermeasures of acid rain pollution in China. J. Anhui Agri. Sci 2010, 38, 19420-19421, 19425.

4. An, T.C.P.; Gao, W.J. Research on acid rain on the right track. World Sci. 1983, 9, 40-42.

5. Tripathi, A.K.; Mukesh, G. Biochemical parameters of plants as indicators of air pollution. J. Environ. Biol. 2007, 28, 127-132.

6. Dwivedi, A.K.; Tripathi, B.D. Pollution tolerance and distribution pattern of plants in surrounding area of coal-fired industries. J. Environ. Biol 2007, 28, 257-263. [PubMed]

7. Zhang, C.Y.; Yi, X.Q.; Gao, X.Z.; Wang, M.H.; Shao, C.Y.; Lv, Z.D.; Chen, J.J.; Liu, Z.H.; Shen, C.W. Physiological and biochemical responses of tea seedlings (Camellia sinensis) to simulated acid rain conditions. Ecotoxicol. Environ. Saf. 2020, 192, 110315. [CrossRef] [PubMed]

8. Jin, Q.; An, W.L.; Liu, X.Y.; Chen, X.X.; Lin, S.Y.; Wang, W.Q. Effects of simulated acid rain on carbon, nitrogen, phosphorus contents and the ecological stoichiometry of rice leaves in Fuzhou rice fields along the river. Acta Ecol. Sin. 2020, 40, 1-11.

9. Chen, X.X.; An, W.L.; Chen, Y.Y.; Liu, X.Y.; Jing, Q.; Lin, S.Y.; Wang, W.Q. Effects of simulated acid rain on soil carbon pool and soil carbon pool management index of paddy field in Fuzhou plain. J. Soil Water Conserv. 2019, 33, 294-302.

10. Wei, H.; Ma, R.; Zhang, J.E.; Saleem, M.; Liu, Z.Q.; Shan, X.R.; Yang, J.Y.; Xiang, H.M. Crop-litter type determines the structure and function of litter-decomposing microbial communities under acid rain conditions. Sci. Total Environ. 2020, 713, 136600. [CrossRef] [PubMed]

11. Liu, Z.Q.; Li, D.F.; Zhang, J.E.; Saleem, M.; Zhang, Y.; Ma, R.; He, Y.N.; Yang, J.Y.; Xiang, H.M.; Wei, H. Effect of simulated acid rain on soil $\mathrm{CO}_{2}, \mathrm{CH}_{4}$ and $\mathrm{N}_{2} \mathrm{O}$ emissions and microbial communities in an agricultural soil. Geoderma 2020, 366, 114222. [CrossRef]

12. Schaefer, M. The soil fauna of a beech forest on limestone: Trophic structure and energy budget. Oecologia 1990, 82, 128-136. [CrossRef] [PubMed]

13. Visser, S. Role of soil invertebrates in determining the composition of soil microbial communities. Ecol. Interact. Soil 1985, 4, 297-317.

14. Anderson, J.M. Spatiotemporal effects of invertebrates on soil processes. Biol Fertil Soils 1988, 6, $216-227$. [CrossRef]

15. Bartlett, M.D.; Briones, M.J.I.; Neilson, R.; Schmidt, O.; Spurgeon, D.J.; Creamer, R. A critical review of current methods in earthworm ecology: From individuals to populations. Eur. J. Soil Biol. 2010, 46, 67-73. [CrossRef]

16. Xu, D.M.; Rao, G.W. Joint effect of co-exposure of $\mathrm{Cu}$ and chlorpyrifos on the toxicity of earthworm. Chin. J. Appl. Ecol. 2016, 27, 3029-3034. 
17. Higgins, C.P.; Mcleod, P.B.; MacManus-Spencer, L.A.; Luthy, R. Bioaccumulation of perfluorochemicals in sediments by the aquatic oligochaete lumbriculus variegatus. Environ. Sci. Technol. 2007, 41, 4600-4606. [CrossRef]

18. Liu, S.; Zhou, Q.X.; Wang, Y.Y. Ecotoxicological responses of the earthworm Eisenia fetida exposed to soil contaminated with HHCB. Chemosphere 2011, 83, 1080-1086. [CrossRef]

19. Qiu, J.P. Earthworms and their application in environment protection II. Ecotoxicology of earthworms. J. Shanghai Agric. Coll. 1999, 17, 301-308. (In Chinese)

20. Fent, K. Ecotoxicological problems associated with contaminatedsites. Toxicol. Lett. 2003, 11, 353-365. [CrossRef]

21. Chen, T. The status quo of soil heavy metal pollution and its remediation measures in China. Xiangcun Keji 2018, 23, 118-121.

22. Dai, J.; Liu, T.H. Pollution Characteristics of Ecological Environment of Vegetable Land in Guangzhou. Chin. J. Soil Sci. 1995, 26, 102-104.

23. An, H.X.; Huang, Z.G. Control measures for heavy metal pollution in acid soils of southern China. China South. Agric. Mach. 2019, 13, 17-22.

24. Xu, X.H.; Xu, G.L. Spatial distribution of acid rain in acid rain pollution controlled area of China based on GIS. J. Shijiazhuang Univ. 2014, 16, 78-83.

25. Xu, X.H.; Gao, H.W. Analysis of the distribution and causes of acid rain in Southern China. Sichuan Environ. 2011, 30, 135-139.

26. Zhang, J.E.; Yu, J.Y.; Ouyang, Y. Activity of Earthworm in latosol under simulated acid rain stress. Bull. Environ. Contam. Toxicol. 2014, 93, 108-111. [CrossRef]

27. Spatzenegger, M.; Jaeger, W. Clinical importance of hepatic cytochrome-P450 in drug-metabolism. Drug Metab. Rev. 1995, 27, 397-417. [CrossRef]

28. Sun, J.H. Human Pregnane X Receptor-Mediated Transcriptional Regulation of CYP3A4 by Six Food Non-Nutrients. Masteri ${ }^{-}$s Thesis, Zhejiang University, Hangzhou, China, 2004.

29. Masuyama, H.; Suwaki, N.; Tateishi, Y.; Nakatsukasa, H.; Segawa, T.; Hiramatsu, Y. The pregnane X receptor regulates gene expression in a ligand-and promoter-selective fashion. Mol. Endocrinol. 2005, 19, 1170-1180. [CrossRef]

30. Takeshita, A.; Koibuchi, N.; Oka, J.; Taguchi, M.; Shishiba, Y.; Ozawa, Y. Bisphenol-A, an environmental estrogen, activates the human orphan nuclear receptor, steroid and xenobiotic receptor-mediated transcription. Eur. J. Endocrinol. 2001, 145, 513-517. [CrossRef]

31. Cao, X.; Han, S.C.; Lv, X.; Li, Z.G.; Fan, Z.W. Effects of simulated acid rain on seed germination and seedling growth of Mikania micrantha H.B.K. Ecol. Environ. Sci. 2010, 19, 679-685.

32. Dai, Z.M.; Liu, X.M.; Wu, J.J.; Xu, J.M. Impact of simulated acid rain on recalcitrance of two different soils. Environ. Sci. Pollut. Res. 2013, 20, 4216-4224. [CrossRef] [PubMed]

33. Sonderfan, A.J.; Arlotto, M.P.; Dutton, D.R.; Mcmillen, S.; Parkinson, A. Regulation of testosterone hydroxulation by rat-liver microsomal cytochrome-P-450. Arch. Biochem. Biophys. 1987, 255, 27-41. [CrossRef]

34. Zhang, T.Y.; Zhu, Y.X.; Gunaratna, C. Rapid and quantitative determination of metabolites from multiple cytochrome $\mathrm{P} 450$ probe substrates by gradient liquid chromatography-electrospray ionization-ion trap mass spectrometry. J. Chromatogr. B-Anal. Technol. Biomed. Life Sci. 2002, 780, 371-379. [CrossRef]

35. Kai, J.R.; Song, Y.F.; Cao, X.F.; Yang, X.X.; Yin, Y.C.; Chen, L. Ecotoxic responses of earthworm Eisenia fetida exposed to cypermethrin. J. Agro-Environ. Sci. 2013, 32, 224-231.

36. Zhou, Y.; Lin, L.; Guo, Y.J.; Liu, Y.; Zhang, L.K.; Liu, D.Y.; Meng, Q.R. Observation of pollen morphologies in nine cultivars of Verbena Linn by Sem. J. Hebei Agric. Univ. 2018, 41, 59-74.

37. Luo, Q.G.; Chen, X.X.; Zhuang, W.Z. Effects of pesticides on romanomermis wuchangensis a mermithid nematode parasite of mosquito larvae. Chin. J. Vector Biol. Control 1991, 2, 73-76.

38. Yu, J.Y. Effect of Simulated Acid Rain on Al Activation in Red Soil and Its Ecotoxicity on Earthworms; South China Agricultural University: Guangzhou, China, 2010.

39. Meng, L.; Zhang, J.E.; Xu, H.Q.; Yu, J.Y.; Qin, Z.; Xie, J.F.; Quan, G.M. Killing effects of compound pollution from the simulated acid rain and its activated $\mathrm{Al}^{3+}$ on small and medium-sized soil animals. Ecol. Environ. Sci. 2011, 20, 1491-1495. 
40. Wang, Y.L. Stress Response of Earthworm to Arsenic Pollution and Its Effects on Soil Physical and Chemical Properties; Shanghai Jiao Tong University: Shanghai, China, 2019.

41. Hu, C.H.; Zheng, L.Z. Effects of Acidic Sediment on Soil Animals. Hubei Sci Technol 1999, 2, 41.

42. Li, Y.; Sun, R. Study on biological effects of simulated acid rain. Sci. Technol. Inf. 2008, 255, 255, 313.

43. Sun, S.J.; Wen, Q.; Xie, P. Research advance on effects of acid rain on soil quality. J. Anhui Agri. Sci 2012, 40, 2774-2777.

44. Fang, K.; Chen, X.M.; Du, Z.J.; Zhang, J.B.; Deng, J.Q.; Sun, J.H.; Zhou, C.M. $\mathrm{SO}_{4}{ }^{2-}$ and $\mathrm{NO}_{3}{ }^{-}$break through situations in representative red soils and prediction by Hydrus-1D model. J. Agro-Environ. Sci. 2009, 28, 107-111.

45. Yang, X.; Xiang, C.G.; Liu, Z.X. Effect of heavy metal pollution on soil animals. Chin. Agric. Sci. Bull. 2008, 24, 454-457.

46. Reinecke, A.J.; Reinecke, S.A.; Maboeta, M.S. Cocoon production and viability as endpoints in toxicity testing of heavy metals with three earthworm species. Pedobiologia 2001, 45, 61-68. [CrossRef]

47. Salminen, J.; Haimi, J. The asexual enchytraeid worm Cognettia sphagnetorum (Oligochaeta) has increased Cu resistance in polluted soil. Environ. Pollut. 2001, 113, 221-224. [CrossRef]

48. Guo, Y.C.; Wang, Z.Z.; Zhang, Y.M.; Lai, Q.; Yan, H.M.; Xia, W.S. Studies on toxicity and toxicology of heavy metals to earthworms in polluted soils. Chin. J. Appl. Environ. Biol 1996, 2, 132-140.

49. Wang, Z.Z.; Zhang, Y.M.; Hu, J.L.; Zheng, Y.Y.; Hu, Z.Y.; Guo, Y.C.; Lai, Q.; Yan, H.M.; Deng, J.F. Effect of heavy metals in soil on earthworms (Opisthopora). Acya Sci. Circumstantiae 1994, 14, 236-247.

50. Li, Z.X.; Huang, Y.X. Effect of suspension $\mathrm{pH}$ on structure and function of single living crocodilian erythrocyte. Chin. Sci. Bull. 2011, 2, 191-194.

51. Shan, S.D.; Yu, J.Y.; Yu, W. Acid rain and soil ecosystem. Eco-Agric. Res. 2000, 8, 20-23.

52. Chen, Q.H.; Sun, M.; Kuang, Q.; Shi, D.L.; Liu, H.; Hu, L.H.; Zhang, W.N.; Xia, D.; Zhu, Q.X. Influence of Cultivation Condition on Sporulation of Bacillus coagulans. Biotechnology 2009, 19, 77-81.

53. Wang, J.L.; Zhou, X.P.; Sun, W. Effects of simulated acid rain on the release of aluminum ion in the soil. Anhui Agric. Sci. Bull. 2016, 22, 28-29, 120.

54. Wang, C.Y. Effect of temperature and $\mathrm{pH}$ value on enzyme activity. Technol. Mark. 2016, 23, 232.

55. Cheng, J.M.; Pan, G.X.; Cang, L.; Yang, J.J.; Wang, J.H. Effect of simulation acid rain on plant and pH of paddy soils in Taihu area. J. Nanjing Agric. Univ. 2000, 23, 116-118.

56. Cen, H.X.; Wang, S.G.; Qiu, R.L.; Ma, L.F. Effect of simulating acid rain on cation release of some soils. Environ. Pollut. Control. 2001, 23, 13-15, 26.

57. Li, Z.L.; Ding, H.T.; Yang, Y.Y.; Chen, X.J.; Zhao, Y.H.; Zhou, Q.F. Activities of cytochrome P450 enzyme CYP102A16 from Bacillus sp. C3. J. Zhejiang Univ. (Agric. Life Sci.) 2012, 38, 662-668.

58. Gu, C.H.; Shan, Z.X. Simulation on releasing characteristics of $\mathrm{Cd}, \mathrm{Zn}$ and $\mathrm{Cu}$ in soil polluted by acid rain. Min. Saf. Environ. Prot. 2010, 37, 6, 13-15, 19.

(C) 2020 by the authors. Licensee MDPI, Basel, Switzerland. This article is an open access article distributed under the terms and conditions of the Creative Commons Attribution (CC BY) license (http://creativecommons.org/licenses/by/4.0/). 